Abstracta Iranica Abstracta Iranica

Revue bibliographique pour le domaine irano-aryen

Volume 31 | 2011

Comptes rendus des publications de 2008

\title{
Kleines Lexikon des Christlichen Orients. Wiesbaden, Harrassowitz, 2007, xlv-655 p.
}

\section{Christelle Jullien}

\section{(2) OpenEdition}

1 Journals

\section{Édition électronique}

URL : http://journals.openedition.org/abstractairanica/39664

DOI : 10.4000/abstractairanica.39664

ISSN : 1961-960X

Éditeur :

CNRS (UMR 7528 Mondes iraniens et indiens), Éditions de l'IFRI

Édition imprimée

Date de publication : 15 mai 2011

ISSN : 0240-8910

Référence électronique

Christelle Jullien, «Kleines Lexikon des Christlichen Orients. Wiesbaden, Harrassowitz, 2007, xlv-655 p. », Abstracta Iranica [En ligne], Volume 31 | 2011, document 216, mis en ligne le 11 octobre 2012, consulté le 26 septembre 2020. URL : http://journals.openedition.org/abstractairanica/39664 ; DOI : https:// doi.org/10.4000/abstractairanica.39664

Ce document a été généré automatiquement le 26 septembre 2020.

Tous droits réservés 


\section{Kleines Lexikon des Christlichen Orients. Wiesbaden, Harrassowitz, 2007, xlv-655 p.}

Christelle Jullien

1 Il s'agit d'une nouvelle édition révisée et actualisée d'un petit dictionnaire de l'Orient chrétien paru initialement en 1975. Cet ouvrage permet d'aborder les grandes thématiques relatives aux christianismes orientaux sous forme simple. De courtes références bibliographiques sont données à la fin de chaque notice.

INDEX

Thèmes : 6.3. Autres religions

\section{AUTEURS}

CHRISTELLE JULLIEN

CNRS - Mondes iranien et indien - Paris 